( Лісяний М.І., 2021

doi:10.37321/immunology.2021.3-02

удК, 612.017.1:616.988:576. 8,097.3:616,071

\title{
ОСОБЛИВОСТІ ГУМОРАЛЬНОГО ІМУНІТЕТУ ПРИ COVID-19 ТА ПЕРСПЕКТИВИ ВИКОРИСТАННЯ ПРОТИВІРУСНИХ АНТИТІЛ В КЛІНІЧНІЙ ПРАКТИЦІ (ОГЛЯД ЛІТЕРАТУРИ)
}

\author{
ЛІСЯНИЙ М.І. \\ Відділ нейроімунології дУ «Інститут нейрохірургії ім. А.П. Ромоданова НАМНУ», м. Київ
}

Відомо, що SARS-CoV-2 вірус є вже сьомим коронавірусом людини, який детально вивчається сьогодні. Перші чотири коронавіруси людини циркулюють сезонно і дають легку застуду. Два інших коронавіруса, а саме SARS і MERS, перейшли від тварин до людини, але не стали ендемічними, тоді як SARS-CoV-2 придбав високу епідемічну активність. Хоча більшість людей, інфікованих SARS-CoV-2, мають захворювання легкого або помірного ступеня тяжкості і лише незначна частина населення переносить інфекцію у важкій формі, що може призводити до смертельних наслідків [1,2]. У таких хворих розвивається гострий респіраторний дистрессиндром, який характеризується дисбалансом у складі лімфоцитів, нейтрофілів та моноцитів у периферичній крові, а також супроводжується накопичуванням нейтрофілів і моноцитів в бронхах та легенях, розвитком «цитокінового шторму» та поширеного запалення, що призводить до пошкодження паренхіми та набряку легень. Однак, чому ця інфекція має такий різний перебіг і від чого це залежить, поки що до кінця не відомо, а роль імунних реакцій, як клітинного, так і гуморального типу, в патогенезі не однозначна та суперечлива [2-4]. Сьогодні існує як мінімум два погляди на цю проблему, а саме противірусна, захисна та імунопатологічна, стимулююча вірусну інфекцію, що реалізується різними чинниками імунної системи, особливо антитілами $[2,4]$. В даний час інформація про імунітет при COVID-19 є не повноцінною і страждає від: (1) відсутності даних про безсимптомну форму перебігу інфекції у людей, яка також супроводжується специфічними клітинними і гуморальними імунними реакціями; (2) поверхневим уявленням про зміни кількості і складу імунних клітин у периферичній крові у хворих прогресуючим перебігом захворювання, та про імунорегуляторні механізми під час інфекції, що відповідають за кліренс вірусу або сприяють його ухиленню від реакцій імунітету; (3) суперечливості даних про направленість та рівень нейтралізуючих і стимулюючих COVID-19 інфекцію антитіл; (4) антитіло-залежну стимуляцію розвитку захворювання [2-5]. Дати відповідь на таку кількість питань по проблемі імунітету при корона інфекції складно в одній статті і тому дана робота буде присвячена лише одному питанню: ролі специфічних антитіл до вірусу COVID-19 та можливості використання антитіл для профілактики та лікування тяжких форм захворювання.

Відомо, що імунна відповідь проти різних вірусів досить неоднорідна. Ефективна дія вродженого імунітету з його клітинними і гуморальними чинниками має основоположне та провідне значення для боротьби в ранні фази первинної вірусної інфекції. Так, наприклад, при респіраторній грипозній інфекції на ранній фазі захворювання захист організму відбувається за рахунок інтерферону I типу (IFN-1), клітин-природних кілерів (NK) та інших клітин вродженого імунітету, а генерація вірус-специфічного CD8+ цитотоксичних Т-лімфоцитів, які можуть контролювати вірусну загрузку, починається через 3-4 дні від початку захворювання. Перші низькоафінні IgМ-специфічні антитіла з'являються через 6-7 днів, тоді як високоафінні IgG і IgA-антитіла визначаються на 3-4 тижні, коли вже хворий позбувся вірусу і видужав [4]. Отже, протигрипозні антитіла мало сприяють у боротьбі з гострою ранньою фазою грипу, хоча вони захищають від повторної інфекції і можуть використовуватися для серопрофілактики та лікування тяжких хворих. В той же час показано, що специфічні антитіла до вірусу SARS-CoV-2 з'являються в крові швидко після зараження і їх рівень часто збігається з прогресуванням захворювання. В одному з перших багатоцентрових досліджень (285 пацієнтів) було вивчено особливості розвитку гуморального імунітету і наростання титру антитіл на SARS-CoV-2. Група з 52 пацієнтів з підозрою на інфекцію COVID-19 і 64 із тих, що були 3 ними в контакті, досліджувались на визначення рівня антитіл методами ІФА [4,5]. Позитивний рівень IgG досяг 100\% приблизно через 20 днів після появи перших симптомів. Середній період сероконверсії як для IgG, так і для IgM, становив 13 днів після появи симптомів. Критерієм сероконверсії для IgG антитіл було $\geq 4$-кратне збільшення титрів IgG в наступних зразках сироватки крові. Така сероконверсія була діагностована у 82,9\% (34/41) пацієнтів. Сероконверсія IgM антитіл відбувалася паралельно з IgG. Рівні IgG у 
100\% пацієнтів (19/19) увійшли в максимальний рівень (платформу) протягом 6 днів після сероконверсії. Тест на антитіла дозволив виявити 4 пацієнта з COVID-19 з 52, у яких інфекція була підтверджена за допомогою ПЛР, і 7 пацієнтів, які контактували з хворими, але мали негативний ПЛР. Отже, специфічні IgM i IgG виявляються одночасно на ранній стадії інфекції. Серологічний тест визначення рівня антитіл корисний для діагностики інфекції SARS-CoV-2 у пацієнтів з підозрою та осіб, що були в контакті з хворими [4]. Аналогічні результати отримані в інших роботах, де сероконверсія специфічних антитіл IgM та IgG спостерігалася вже на 4-й день після появи симптомів хвороби. У пацієнтів 3 підтвердженим COVID-19 чутливість, специфічність IgМ антитіл склали 77,3\% (51/66), 100\%, а у $\operatorname{lgG}$ - 83,3\% (55/66), 95,0\%. У пацієнтів з підозрою на COVID-19 чутливість, специфічність IgM становили 87,5\% (21/24), 100\%, a IgG - 70,8\% (17/24), 96,6\%. Обидва типи специфічних антитіл, подібно ПЛР, показали велику специфічність при діагностиці COVID-19. Проте антитіла проти SARS-CoV-2 можуть бути виявлені в середній і пізній стадії захворювання у хворих, коли ПЛР уже негативна, а також у підозрюваних на наявність інфекції, що важливо для визначення популяційного імунітету, а також при діагностиці хворих з легкими формами COVID-19 [5]. Дослідження сероконверсії SARS-CoV-2 IgM i IgG у 54 пацієнтів з COVID-19, підтверджених методом плР показало, що чутливість і специфічність для визначення серопозитивності становила $\geq 15$ днів, склали 100,0\% і 98,7\% при аналізі панелі IgM i IgG, антитіл, після позитивного результату ПЛР SARS-CoV-2. Середній час наростання серопозитивності характерний для IgM i IgG при позитивній ПЛР, склало 5 днів (IQR: 2,75-9 днів) i 4 дні (IQR: 2,75-6,75 днів) відповідно [6].

Підвищений рівень IgG або IgM антитіл до COVID-19 може визначатися і в здорових осіб. Так, з 215 обстежених умовно здорових осіб, які контактували з хворими на інфекцію COVID-19, у 9 осіб (3,3\%) виявлявся підвищений рівень антитіл. Позитивний рівень IgG або $\lg$ М антитіл підтвердив COVID-19 інфекцію як у пацієнтів з симптомами, так і у пацієнтів без симптомів і збігався з результатами дослідження ПЛР. Це вказує ще раз на те, що комбінація ПЛР з ІФА повинна використовуватися не тільки для хворих, але і для виявлення безсимптомних випадків і відстеження осіб, що контактують з хворими, це може полегшити ранню діагностику, спостереження, швидку ізоляцію та лікування $[4,7]$. При дослідженні рівня антитіл до COVID-19 у здорових людей у Сан-Франціско, США, було показало, що серопозитивність становила 0,26\% 3 387 госпіталізованих пацієнтів з іншими не респіраторними захворюваннями і 0,1\% у 1000 об- стежених донорів крові. Нейтралізуючі антитіла підвищуються в тандемі з рівнями IgG або IgM антитіл після появи симптомів захворювання, і між ними існує у 93\% випадках позитивна кореляція [8]. Отже, цими та іншими роботами показано, що в крові хворих з SARS-CoV-2 інфекцією специфічні антитіла з>являються з 4-6 дня після початку захворювання, їх кількість продовжує збільшуватися до 15-20 дня хвороби. Рівень антитіл в крові пропорційний тяжкості хвороби, при важких формах хвороби рівень їх вищий, хоча при летальних випадках можливо виявлення і низьких титрів антитіл до SARS-CoV-2 в крові $[4,6]$. Другою особливістю специфічних антитіл до SARS-CoV-2 вірусу є те, що вони визначаються від 1\% до 9\% у здорових осіб, які не мають ознак хвороби, а лише були в контакті з хворими, а також і те, що і при легких, малосимптомних формах інфекції, антитіла можуть виявлятися в крові, хоча їх рівні можуть бути різними. Це все в сукупності указує на те, що при інфекції SARS-CoV-2 виробляються специфічні антитіла, за якими можна визначати як наявність різних по тяжкості форм інфекції, так і стан популяційного імунітету. У той же час потрібно відзначити, що IgM i IgG противірусні антитіла можуть володіти як нейтралізуючими, так і не нейтралізуючими вірусними властивостями.

Основною мішенню для нейтралізуючих антитіл на коронавірусі SARS-CoV-2 $€$ «spike» (S) - білок гомотримерний глікопротеїн, закріплений до вірусної мембрани. Недавні дослідження показали, що S-білок SARS-CoV-2 має значну структурну гомологію з SARS-CoV, причому S-білок складається 3 двох субдоменів: $\mathrm{N}$-кінцевого домену S1, який містить $\mathrm{N}$-кінцевий домен (NTD) і має рецептор-зв язуючий домен (RBD) для ангіотензинперетворюючого ферменту-2 рецептора, який експресується на клітинах паренхіми легень, а другий S2 субдомен містить злитий пептид $[9,10]$.

Останнім часом у зв язку з епідемією акцент вивчення змістився з перехресно нейтралізучих антитіл до SARS-CoV на ізоляцію нових нейтралізуючих антитіл до SARS-CoV-2 від пацієнтів, які видужали від COVID-19 інфекції. Фрагменти білка S, що містять RBD, індукували великий спектр та кількість антитіл, які можуть нейтралізувати SARS-CoV-2 шляхом націлювання на різні RBD-епітопи $[11,12]$. Крім того, з огляду на високу ідентичність послідовностей між субдоменами S2 SARS-CoV-2 і SARS-CoV вірусів, використання повного ектодомена S-білка замість тільки RBD може дозволити отримувати моноклональні нейтралізуючі антитіла, які перехресно можуть нейтралізовувати різні -коронавіруси $[14,15]$.

Проте, мало що відомо про рівень вірусонейтралізуючих антитіл до SARS-CoV-2 (1-5), який 
не завжди співпадає з титрами антитіл, що визначається методом ІФА $[6,8,16]$. Так, плазма, зібрана у 149 видужуючих від інфекції людей, в середньому через 39 днів після появи симптомів захворювання мала різні рівні титрів антитіл, що нейтралізують in vitro псевдокорона вірус: так, титр антитіл менш 1:50 був у 33\% пацієнтів, менше 1:1000 у 79\%, і тільки у 1\% реконвалесцентів рівень антитіл перевищували 1:5000. Незважаючи на низькі титри нейтралізуючих антитіл в плазмі, рівень антитіл до трьох інших епітопів на RBD протеїну був підвищений. Таким чином, плазма більшості видужуючих від COVID-19, не містить високих рівнів нейтралізуючих антитіл, хоча титри IgM i IgG противірусних антитіл були високими [16]. Нейтралізуючі антитіла відіграють важливу роль в очищенні від вірусів і вважаються важливим імунним фактором для захисту від вірусних захворювань. Так, дослідження методом ІФА у 7 повністю безсимптомних пацієнтів і 17 пацієнтів з пневмонією COVID - 19 показало, що у безсимптомних осіб позитивні результати були у 5 (71\%), граничний результат у 1 (14\%) і негативний результат у 1 (14\%) пацієнта. ІФА дослідження у пацієнтів з пневмонією показало більш високе значення рівня антитіл і титри антитіл, що корелювали з тяжкістю захворювання. Всі пацієнти показали наявність нейтралізуючих антитіл в крові. Середній геометричний титр нейтралізуючих антитіл у всіх безсимптомних пацієнтів і у 4 пацієнтів з пневмонією дорівнював 1:50-1:78, і 1:256 у пацієнтів з легкою пневмонією, а у пацієнтів з тяжкою пневмонією рівнявся 1:3158. Таким чином показано, що рівень нейтралізуючих антитіл у безсимптомних пацієнтів з COVID-19 і у 30\% одужалих пацієнтів з легкою формою COVID-19 був недостатнім для нейтралізації вірусу в культурі клітин [17-19]. Отже, плазма, зібрана у пацієнтів, що одужали, може мати різні рівні вірусонейтралізуючих антитіл.

Наведені дані показують, що як у тяжких, так і у безсимптомних хворих в крові можуть бути віруснейтралізуючі антитіла, але їх рівень може бути різним і знижуватися з часом. Ці, поки перші, дані потребують підтвердження іншими дослідженнями, але в той же час вони вказують на необхідність тестування рівня нейтралізуючих антитіл в плазмі, особливо з лікувальною метою при застосуванні у хворих з важкою формою хвороби. 3 огляду на те, що метод визначення нейтралізуючих вірусних антитіл in vitro дуже складний і вимагає наявності живого реального чи псевдо вірусу, наприклад. BetaCoV/ Korea/SNU01/2020 virus. Ряд авторів пропонує визначати рівень антитіл методом ІФА, які у гострій фазі захворювання корелюють з рівнем вірус нейтралізуючих антитіл, але чи буде така залежність у реконвалесцентів через 3-6 і більше місяців, невідомо. Якщо оцінювати за рівнем антитіл до інших споріднених коронавірусів, 3окрема SARS-CoV вірус, то відомо, що IgG антитіла проти білка N можна виявити в сироватці вже через 4 дні після початку захворювання, ґрунтуючись на ІФА аналізі, при цьому у більшості пацієнтів рівні антитіл наростали до 14 дня [20-21]. Пік IgG і нейтралізуючих антитіл досягав максимуму через 4 місяці, а потім поступово знижується [22]. У 89\% пацієнтів, які видужали, виявляються антитіла IgG до SARS-CoV і через 24 місяці після зараження [21]. Проте, тяжкість захворювання також може впливати на час появи і величину титру антитіл. Показано, що у пацієнтів, інфікованих SARS-CoV, які мали летальні наслідки, спостерігається недостатня продукція антитіл проти білка S в порівнянні з пацієнтами без важких форм захворювання [22]. Під час тривалого спостереження за пацієнтами, які вижили після SARS-CoV інфекції, IgG антитіла виявлялись тільки у 2 з 23 пацієнтів через 6 років після початку захворювання [23], що вказує на поступове зниження рівня В-клітин пам>яті і рівня антитіл проти SARS-CoV.

На жаль, тривалість гуморального імунітету та рівень антитіл для SARS-CoV-2 вірусу ще глибоко не вивчені, але, беручи до уваги наведені вище дані, можна думати, що титри нейтралізуючих SARS-CoV-2 вірус-антитіл з часом будуть зменшуватись як після перенесеної інфекції, так і після вакцинації, що ставить на повістку дня цілий ряд питань, таких як наявність імунітету після захворювання, розвиток повторних захворювань під час пандемії, ефективність вакцинації та тривалість імунітету після неї та інше. Необхідно відмітити, що антитіла, крім нейтралізації вірусу шляхом прямого блокування певних його антигенів, можуть забезпечувати противірусний захист за допомогою інших механізмів, таких як фактори комплементу та Fc-фрагментів імуноглобулінів, рецептори для яких і присутні на всіх імунних клітинах [24]. Ці, не прямо нейтралізуючі вірус антитіла, ще називають «екстранейтралізуючі антитіла» [24,25], можуть включати для захисту від інфекції різні за механізмами імунні реакції , такі як антитіло-залежний клітинний фагоцитоз, комплемент-залежну та антитіло-залежну клітинну цитотоксичність, що складають основу клітинного імунітету. Екстранейтралізуючі функції антитіл пов язані з захистом від багатьох інфекційних захворювань, проте в деяких випадках ці антитіла можуть посилювати ушкодження різних тканин та визивати імунопатологію $[24,25]$. Зрозуміло, що такі властивості антитіл, які не прямо нейтралізують вірус, а діють через відповідні імунні клітини чи фактори комплементу, знаходяться лише на початку вивчення, але вони важливі для розуміння механізмів захисту від інфекції. 
Таким чином, на сьогодні повного уявлення про те, як антитіла можуть виконувати захисні і потенційно патогенні ролі при SARS-CoV-2, ще немає. До цих пір, єдиний доказ в підтримку ролі опосередкованого антитілами посилення захворювання пов)язано з наявністю високих рівнів антитіл у людей з важким перебігом інфекції [17,18,24]. Крім того, антитіла можуть просто накопичуватися в якості біомаркерів високої дози антигену. Причинний зв>язок між кількістю антитіл і тяжкістю захворювання у людей залишається неясним. Хоча відомо, що при лихоманці Денге чи Ебола, високі рівні антитіл після вакцинації або після хвороби були здатні посилювати тяжкість інфекції, що пов'язується з антитіло залежним стимулюванням захворювання [3,4]. Даних про такі властивості антитіл при COVID-19 поки що немає, але, ймовірно, на це вказує той факт, що при важкому варіанті корона-інфекції, особливо у літніх хворих, визначається високий рівень антитіл, які можуть сприяти проникненню вірусів до клітин за допомогою Fc-фрагментів імуноглобулінів та ускладнювати перебіг захворювання.

Вивчення взаємозв язку міжтитрами lgM ilgG противірусних антитіл проти спайк-ектодомена (ECD) і рецептор-зв язуючого домену (RBD), і титрами нейтралізуючих SARS-CoV-2 вірус антитіл in vitro, було проведено з використанням зразків плазми, отриманих від 68 пацієнтів 3 COVID-19. Виявлено сильну позитивну кореляцію між титрами анти-RBD і анти-ECD в плазмі крові, які визначалися методом ІФА і титром НТА in vitro. Проте, 37\% (25/68) зразків плазми не мали високих титрів нейтралізуючих антитіл, які перевищували б розведення $\geq 1: 160$, що рекомендується при використанні плазми пацієнтів, які перехворіли, для лікування важких випадків COVID-19. Аналіз сироватки крові 2814 дорослих, які не мають симптомів хвороби, виявив у 27 осіб (0,95\%) анти-RBD або анти-ECD антитіла IgG з титрами $\geq 1: 1350$ і нейтралізуючі антитіла понад $\geq 1: 160$, що вказує на безсимптомний перебіг інфекції $[27,28]$. Автори роблять висновок, що високі титри анти-RBD або анти-ECD IgG можуть служити додатковим індикатором рівня (сурогатом) титрів нейтралізуючих антитіл для ідентифікації відповідних донорів плазми.

Вірус-специфічні антитіла, які індуковані в результаті інфекції або вакцинації, мають здатність заблокувати вірусну інфекцію і залишаються в якості золотого стандарту для оцінки ефективності вакцин проти вірусів віспи, поліомієліту, грипу та інших інфекцій.

Терапія антитілами, наприклад, введення плазми крові пацієнтів, що перехворіли, була успішно використана для лікування багатьох інфекційних вірусних захворювань, включаючи віpyc SARS-CoV, грипу, лихоманки Ебола та інші
[3,30]. Ефективність пасивної терапії антитілами була пов язана з концентрацією нейтралізуючих антитіл у плазмі пацієнтів чи вакцинованих. На сьогодні, під час пандемії COVID-19, переливання реконвалесцентної плазми або сироватки від пацієнтів, які видужали, також розглядається як перспективний метод лікування та профілактики даної інфекції.

Паралельно з використанням специфічних противірусних антитіл від пацієнтів, які перехворіли, перспективним методом лікування $€$ використання моноклональних антитіл (mAb) проти певних антигенів SARS-CoV-2, які можуть відігравати ефективну роль у контролі CoV-інфекцією. Для клінічного дослідження уже запропоновано використання багато наборів моноклональних антитіл, які функціонально націлені на різні специфічні домени в S білку MERS-CoV вірусу. Так, моноклональні антитіла, що можуть зв язуватись з шістьма різними специфічними епітопними групами вірусу [31,32]. Використання таких антитіл може представляти новий підхід до посилення гуморального захисту від CoVs шляхом націлювання на різні епітопи і функції S-білка, які пов'язані 3 нейтралізацією вірусу. Показана перехресна нейтралізуюча специфічність моноклональних антитіл до різних штамів CoV вірусу, що пов'язано з амінокислотною подібністю їх протеїнів [32]. Такі перехресно(крос) нейтралізуючі специфічні для SARS-CoV RBD антитіла можуть бути ефективні і при SARS-CoV-2 інфекції, і уже проводиться їх оцінка в умовах клініки [33].

Уже існують різні технології для створення повністю людських моноклональних антитіл, на які не буде імунної відповіді (таких як одноланцюгові антитіла людини; Hu-scFvs) чи гуманізовані нанотіла (з одним доменом, sdAb, VH/VHH), чи які можуть проникати через мембрану інфікованих вірусом клітин (транс-тіла) і зв язуватись з вірусом та перешкоджати реплікації вірусних білків та гальмувати біологічну активність вірусу [34]. Проте, на жаль, поки що широкого клінічного використання моноклональні антитіла ще не мають з різних причин, в тому числі з незначної вірусонейтралізуючої активності готових препаратів.

Безумовно, використання сучасних технологій лікування та попередження Covid-19 дозволить зробити цю інфекцію контрольованою, але все це буде в майбутньому. На сьогодні ще залишається багато не вивчених та незрозумілих питань, які пов'язані з особливістю імунітету при цій інфекції і поки ведеться пошук специфічних противірусних препаратів та вакцин, основним традиційним методом направленого лікування залишається використання в клінічній практиці специфічних антитіл у вигляді плазми, сироватки чи очищених імуноглобулінів пацієн- 
тів, які вже перехворіли. Як показують численні дослідження стану гуморального імунітету при корона-інфекції, потрібно враховувати кілька принципових застережень при клінічному використані специфічних противірусних сироваток чи антитіл. По-перше, не в усіх осіб, що перехворіли, в крові достатній рівень нейтралізуючих антитіл, щоб їх сироватку чи плазму можна було б одразу використовувати для лікування тяжких хворих, так від 30 до 50\% зразків крові реконвалесцентів містять низькі захисні рівні антитіл. По-друге, застереження, пов'язане з вірус нейтралізуючою активністю антитіл, яка з одного боку не завжди співпадає з рівнем антитіл, що визначаються методом ІФА, а з іншого - це може бути пов'язано з синтезом при інфекції широкого спектру антитіл до різних антигенів чи епітопів вірусних протеїнів, кількість яких переважає 30, значна частина цих антитіл не має вірусонейтралізуючої активності і не може захистити від інфекції. Так, існує досить велика кількість варіантів отримання моноклональних антитіл до різних антигенів чи специфічних антигенних детермінант коронавірусу, але більшість із них не виявляє достатньої вірусної нейтралізуючої активності в умовах культури клітин, і це гальмує широке використання моноклональних антитіл 3 лікувальною та профілактичною метою. Швидке вирішення питання про антигени вірусу, які відповідають за синтез саме вірусонейтралізуючих моноклональних антитіл, дозволить значно розширити асортимент препаратів для лікування даної інфекції як на основі класичних моноклональних антитіл і різних сучасних біотехнологічних їх варіантів (гуманізовані антитіла, наноантитіла, Fab фрагменти та інші), так і імунних препаратів із крові реконвалесцентів та вакцинованих донорів. Третя засторога, це особливості продукції антитіл після штучної вакцинації проти коронавірусу, які з одного боку не завжди мають високу віруснейтралізуючу активність і синтезуються на короткий термін, що може приводити до виникнення інфекції у вакцинованих, а з іншого - відомо, що високий рівень антитіл в крові, особливо у літніх людей, часто обтяжує перебіг захворювання і може викликати антитіло-залежне підсилення інфекції за рахунок Fc фрагментів імуноглобулінів та «екстра нейтралізуючих» властивостей таких антитіл.

Не дивлячись на велику кількість публікацій та перераховані застороги, існує ще цілий ряд невирішених проблем, пов'язаних з особливостями специфічного гуморального імунітету при Covid-19 та вакцинації, які потрібно вирішити. Насамперед, це противірусна нейтралізуюча активність антитіл, тривалість імунітету після інфекції чи вакцинації та можливість попередження та лікування тяжких форм захворювання препаратами із крові перехворілих. Хочеться думати, що імунні препарати із крові реконвалесцентів та біотехнологічні моноклональні антитіла, які містять достатній рівень нейтралізуючих антитіл, стануть доступним специфічним засобом лікування та попередження інфекції Covid-19.

\section{ЛITEPATУPA:}

1. Задорожна В.І. Винник Н.П. Корона вірус 2019 - nCOV: нові виклики охороні здоров'я та людству. Інфекційні хвороби 2020. №2 с.1-9. doi: 10.11603/16812727.2020.1.11091. Zadorozhna VI Vinnik NP Crown Virus 2019 - nCOV: New Challenges for Health and Humanity. Infectious diseases 2020. №2 p.1-9. doi: 10.11603 / 16812727.2020.1.11091

2. Zost S.J., Gilchuk P., Case J.B., Binshtein E., Chen R.E., Reidy J.X., Trivette A., Nargi R.S., Sutton R.E., Suryadevara N., Williamson L.E., Chen E.C., Jones T., Day S., Myers L., Hassan A.O., Kafai N.M., Winkler E.S., Fox J.M., Steinhardt J.J., Ren K., Loo Y.-M., Kallewaard N.L., Martinez D.R., Schäfer A., Gralinski L.E., Baric R.S., Thackray L.B., Diamond M.S., Carnahan R.H., \& Crowe Jr. J.E. (2020). Potently neutralizing human antibodies that block SARS-CoV-2 receptor binding and protect animals. bioRxiv., Preprint. 2020 May 22. doi:10.1101/2020.05.22.111005. PMCID: PMC7263556; PMID: 32511409.

3. van Griensven, J, Edwards, T, de Lamballerie, $X$, Semple, MG, Gallian, P, Baize, S, Horby, PW, Raoul, H, Magassouba, N, Antierens, $A$, Lomas, $C$, Faye, $O$, Sall, AA, Fransen, $K$, Buyze, J, Ravinetto, R, Tiberghien, P, Claeys, Y, De Crop, M, Lynen, L, Bah. El, Smith. PG, Delamou, A, De Weggheleire, A, \& Haba, N. (2016). Evaluation of convalescent plasma for Ebola virus disease in Guinea. N Engl J Med., 374, 33-42. doi:10.1056/NEJMoa1511812. PMID:26735992.

4. Long, $Q-X$, Deng, $H-J$, Chen, J, Hu, J, Liu, $B-Z$, Liao, $P$, Lin, $Y, Y u, L-H, M o, Z, X u, Y-Y$, Gong, $F$, Wu, G-C, Zhang, $X-X$, Chen, $Y-K$, Li, Z-J, Wang, K, Zhang, X-L, Tian, W-G, Niu, C-C, Yang, Q-J, Xiang, J-L, Du, H-X, Liu, $H-W$, Lang, C, Luo, X-H, Wu, S-B, Cui, X-P, Zhou, Z, Wang, J, Xue, C-J, Li, X-F, Wang, L, Tang, X-J, Zhang, Y, Qiu, J-F, Liu, X-M, Li, $J-J$, Zhang, D-C, Zhang, F, Cai, X-F, Wang, $D, H u, Y, R e n, J-H$, Tang, N, Liu, $P, L i, Q$, \& Huang, A-L. (2020). Antibody responses to SARS-CoV-2 in COVID-19 patients: the perspective application of serological tests in clinical practice. medRxiv., [published online ahead of print March 20, 2020]. doi: 10.1101/2020.03.18.20038018. 
5. Xiang, $F$, Wang, $X, H$,,$X$, Peng, Z, Yang, $B$, Zhang, J, Zhou, Q, Ye, H, Ma, Y, Li, H, Wei, X, Cai, $P$, \& Ma, WL. (2020). Antibody Detection and Dynamic Characteristics in Patients with COVID-19. Clin Infect Dis., ciaa461. doi: 10.1093/cid/ciaa461. Online ahead of print. PMID: 32306047.

6. Suhandynata, RT, Hoffman, MA, Kelner, MJ, McLawhon, RW, Reed, SL, \& Fitzgerald, RL. (2020). Longitudinal Monitoring of SARSCoV-2 IgM and IgG Seropositivity to Detect COVID-19. J Appl Lab Med. PMID: 32428207; PMCID: PMC7313967. DOI:10.1093/jalm/ jfaa079.

7. Hung, IF, Cheng, VC, Li, X, Tam, AR, Hung, DL, Chiu, KH, Yip, CC, Cai, JP, Ho, DT, Wong, SC, Leung, SS, Chu, MY, Tang, MO, Chen, JH, Poon, RW, Fung, AY, Zhang, RR, Yan, EY, Chen, LL, Choi, CY, Leung, KH, Chung, TW, Lam, SH, Lam, TP, Chan, JF, Chan, KH, Wu, TC, Ho, $P L$, Chan, JW, Lau, CS, To, KK, \& Yuen, KY. (2020). SARS-CoV-2 shedding and seroconversion among passengers quarantined after disembarking a cruise ship: a case series. Lancet Infect Dis., S1473-3099(20)30364-9. PMID: 32539986; PMCID: PMC7292581. DOI: 10.1016/S1473-3099(20)30364-9.

8. Ng, D, Goldgof, G, Shy, B, Levine, A, Balcerek, J, Bapat, SP, Prostko, J, Rodgers, M, Coller, $K$, Pearce, S, Franz, S, Du, L, Stone, M, Pillai, $S$, Sotomayor-Gonzalez, A, Servellita, V, Sanchez-San Martin, C, Granados, A, Glasner, DR, Han, LM, Truong, K, Akagi, N, Nguyen, DN, Neumann, N, Qazi, D, Hsu, E, Gu, W, Santos, YA, Custer, B, Green, V, Williamson, P, Hills, NK, Lu, CM, Whitman, JD, Stramer, S, Wang, C, Reyes, K, Hakim, J, Sujishi, K, Alazzeh, F, Pharm, L, Oon, C-Y, Miller, S, Kurtz, T, Hackett, J, Simmons, G, Busch, MP, \& Chiu, CY. (2020). SARS-CoV-2 Seroprevalence and Neutralizing Activity in Donor and Patient Blood From the San Francisco Bay Area. medRxiv, 2020 May 25. Preprint. PMID: 32511477; PMCID: PMC7273245. DOI: 10.1101/2020.05.19.20107482.

9. Wrapp, D, Wang, N, Corbett, KS, Goldsmith, JA, Hsieh, CL, Abiona, O, Graham, BS, \& McLellan, JS. (2020). Cryo-EM structure of the 2019-nCoV spike in the prefusion conformation. Science, 367(6483), 1260-1263. doi: 10.1126/science.abb2507. PMID: 32075877.

10. Walls, AC, Park, YJ, Tortorici, MA, Wall, A, McGuire, AT, \& Veesler, D. (2020). Structure, function, and antigenicity of the SARS-CoV-2 spike glycoprotein. Cell, 181(2), 281-292. e6. doi: 10.1016/j.cell.2020.02.058. PMID: 32155444 ; PMCID: PMC7102599.
11. Li, F. (2016). Structure, function, and evolution of coronavirus spike proteins. Annu Rev Virol., 3(1), 237-261. doi: 10.1146/annurevvirology-110615-042301. PMID: 27578435.

12. Shang, J, Ye, G, Shi, K, Wan, Y, Luo, C, Aihara, $H$, Geng, Q, Auerbach, A, \& Li, F. (2020). Structural basis of receptor recognition by SARS-CoV-2. Nature, 581(7807), 221-224. doi: 10.1038/s41586-020-2179-y. PMID: 32225175.

13. Jiang, S, Hillyer, C, \& Du, L. (2020). Neutralizing antibodies against SARS-CoV-2 and other human coronaviruses. Trends Immunol., 41(5), 355-359. doi: 10.1016/j.it.2020.03.007. PMID: 32249063.

14. Pinto D, Park $Y$-J, Beltramello $M$, Walls $A C$, Tortorici MA. Bianchi S, Jaconi S, Culap K, Zatta $F$, Marco $A D$, Peter $A$, Guarino $B$, Spreafico R, Cameroni E, Case JB, Chen RE, Havenar-Daughton $C$, Snell $G$, Telenti $A$, Virgin HW, Lanzavecchia A, Diamond MS, Fink K, Veesler D, \& Corti D. (2020). Structural and functional analysis of a potent Sarbecovirus neutralizing antibody. bioRxiv, 2020 Apr 9; 2020.04.07.023903. doi: 10.1101/2020.04.07.023903. Preprint. PMID: 32511354 ; PMCID: PMC7255795.

15. Tian, X, Li, C, Huang, A, Xia, S, Lu, S, Shi, Z, Lu, L, Jiang, S, Yang, Z, Wu, Y, \& Ying, T. (2020). Potent binding of 2019 novel coronavirus spike protein by a SARS coronavirus-specific human monoclonal antibody. Emerg. Microbes Infect., 9, 382385. doi: 10.1080/22221751.2020.1729069. PubMed: 32065055.

16. Kannan, S, Shaik Syed Ali, $P$, Sheeza, A, \& Hemalatha, K. (2020). COVID-19 (Novel Coronavirus 2019) - Recent Trends. Eur Rev Med Pharmacol Sci, 24(4), 2006-2011. doi: 10.26355/eurrev_202002_20378. PMID: 32141569.

17. Lou, B, Li, TD, Zheng, SF, Su, YY, Li, ZY, Liu, W, Yu, F, Ge, SX, Zou, QD, Yuan, Q, Lin, S, Hong, CM, Yao, $X Y$, Zhang, $X J, W u, D H$, Zhou, GL, Hou, WH, Li, TT, Zhang, YL, Zhang, SY, Fan, J, Zhang, J, Xia, NS, \& Chen Y. (2020). Serology characteristics of SARSCoV-2 infection since the exposure and post symptoms onset. Eur Respir J, 56(1). doi: 10.1183/13993003.00763-2020. Online ahead of print. PMID: 32430429.

18. Choe, PG, Kang, CK, Suh, HJ, Jung, J, Kang, E, Lee, SY, Song, KH, Kim, HB, Kim, NJ, Park, WB, Kim, ES, \& Oh, MD. (2020). Antibody Responses to SARS-CoV-2 at 8 Weeks Postinfection in Asymptomatic Patients. Emerg Infect Dis., 26(10). doi: 10.3201/eid2610.202211. Online ahead of print. PMID: 32579877. 
19. Zohar, T, \& Alter, G. (2020). Dissecting antibody-mediated protection against SARSCoV-2. Nat Rev Immunol., 20(7), 392-394. doi: $10.1038 / \mathrm{s} 41577-020-0359-5$. PMID: 32514035

20. Chan, KH, Chan, JF, Tse, $H$, Chen, H, Lau, CC, Cai, JP, Tsang, AK, Xiao, X, To, KK, Lau, SK, Woo, $P C$, Zheng, BJ, Wang, $M$, \& Yuen, $K Y$. (2013). Cross-reactive antibodies in convalescent SARS patients 'sera against the emerging novel human coronavirus. J Infect. , 67(2), 13040. PMID: 23583636; PMCID: PMC7112694. DOI: $10.1016 /$ j.jinf.2013.03.015.

21. Liu, W, Fontanet, A, Zhang, PH, Zhan, L, Xin, ZT, Baril, L, Tang, F, Lv, H, Cao, WC. (2006). Two-year prospective study of the humoral immune response of patients with severe acute respiratory syndrome. J Infect Dis., 193(6), 792-5. doi: 10.1086/500469. PMID: 16479513; PMCID: PMC7109932.

22. Cameron, MJ, Ran, L, Xu, L, Danesh, A, Bermejo-Martin, JF, Cameron, CM, Muller, MP, Gold, WL, Richardson, SE, Poutanen, SM, Willey, BM, DeVries, ME, Fang, Y, Seneviratne, $C$, Bosinger, SE, Persad, D, Wilkinson, $P$, Greller, LD, Somogyi, R, Humar, A, Keshavjee, S, Louie, M, Loeb, MB, Brunton, J, McGeer, AJ; Canadian SARS Research Network, \& Kelvin, DJ. (2007). Interferon-mediated immunopathological events are associated with atypical innate and adaptive immune responses in patients with severe acute respiratory syndrome. J Virol., 81(16), 8692-706. doi: 10.1128/JVI.00527-07. PMID: 17537853; PMCID: PMC1951379.

23. Tang, F, Quan, $Y, X i n, Z T$, Wrammert, J, Ma, $M J, L v, H$, Wang, TB, Yang, $H$, Richardus, JH, Liu, W, \& Cao, WC. (2011). Lack of peripheral memory B cell responses in recovered patients with severe acute respiratory syndrome: a sixyear follow-up study. J Immunol., 186(12), 7264-8. doi: 10.4049/jimmunol.0903490. PMID: 21576510.

24. Fan, Wu, Aojie Wang, Mei Liu, Qimin Wang, Jun Chen, Shuai Xia, Yun Ling, Yuling Zhang, Jingna Xun, Lu Lu, Shibo Jiang, Hongzhou Lu, Yumei Wen, \& Jinghe Huang. (2020). Neutralizing antibody responses to SARSCoV-2 in a COVID-19 recovered patient cohort and their implications. medRxiv. doi: https:// doi.org/10.1101/2020.03.30.20047365. DOI: 10.2139/ssrn.3566211.

25. Lu, R, Zhao, $X, L i, J, N i u, P$, Yang, $B, W u$, $H$, Wang, $W$, Song, $H$, Huang, $B$, Zhu, $N, B i, Y$, Ma, X, Zhan, F, Wang, L, Hu, T, Zhou, H, Hu, Z, Zhou, W, Zhao, L, Chen, J, Meng, Y, Wang, J, Lin, Y, Yuan, J, Xie, Z, Ma, J, Liu, WJ, Wang,
$D, X u, W$, Holmes, EC, Gao, GF, Wu, G, Chen, W, Shi, W, \& Tan, W. (2020). Genomic characterisation and epidemiology of 2019 novel coronavirus: implications for virus origins andreceptor binding. Lancet, 395(10224), 56574. DOI: 10.1016/s0140-6736(20)30251-8. PMID: 32007145; PMCID: PMC7159086.

26. Hoffmann, M, Hannah, K-W, Krüger, $N$, Müller, $M$, Drosten, $C$, \& Pöhlmann, S. (2020). The novel coronavirus 2019 (2019$\mathrm{nCoV})$ uses the SARS-coronavirus receptorACE2 and the cellular protease TMPRSS2 for entry into target cells. bioRxiv. DOI: 10.1101/2020.01.31.929042. [Preprint].

27. Salazar, E, Kuchipudi, SV, Christensen, PA, Eagar, TN, Yi, X, Zhao, P, Jin, Z, Long, SW, Olsen, RJ, Chen, J, Castillo, B, Leveque, C, Towers, DM, Lavinder, J, Gollihar, JD, Cardona, J, Ippolito, GC, Nissly, RH, Bird, IM, Greenawalt, $D$, Rossi, RM, Gontu, A, Srinivasan, S, Poojary, IB, Cattadori, IM, Hudson, PJ, Joselyn, N, Prugar, L, Huie, K, Herbert, A, Bernard, DW, Dye, J, Kapur, V, \& Musser, JM. (2020). Relationship between Anti-Spike Protein Antibody Titers and SARS-CoV-2 In Vitro Virus Neutralization in Convalescent Plasma. bioRxiv, 2020 Jun 9:2020.06.08.138990. Preprint. doi: $10.1101 / 2020.06 .08 .138990$. PMID: 32577662; PMCID: PMC7302218.

28. Seesuay W, Jittavisutthikul S, Sae-Lim N, Sookrung N, Sakolvaree Y, Chaicumpa W. Human transbodies that interfere with the functions of Ebola virus VP35 protein in genome replication and transcription and innate immune antagonism. Emerging Microbes Infect. 2018;7(1):41. doi:10.1038/s41426018-0031-3. [Taylor \& Francis Online], [Google Scholar]

29. Widjaja, I, Wang, $C$, van Haperen, R, GutiérrezÁlvarez, J, van Dieren, B, Okba, NMA, Raj, VS, $L i$, W, Fernandez-Delgado, $R$, Grosveld, $F$, van Kuppeveld, FJM, Haagmans, BL, Enjuanes, L, Drabek, D, \& Bosch, BJ. (2019). Towards a solution to MERS: protective human monoclonal antibodies targeting different domains and functions of the MERS-coronavirus spike glycoprotein. Emerging Microbes Infect., 8(1), 516-530. doi:10.1080/22221751.2019.1597 644. PMID: 30938227; PMCID: PMC6455120.

30. Seesuay, W, Jittavisutthikul, S, Sae-Lim, N, Sookrung, N, Sakolvaree, $Y$, \& Chaicumpa, $W$. (2018). Human transbodies that interfere with the functions of Ebola virus VP35 protein in genome replication and transcription and innate immune antagonism. Emerging Microbes Infect., 7(1), 41. doi:10.1038/ s41426-018-0031-3. PMID: 29568066; PMCID: PMC5864874. 
31. Goo, J, Jeong, Y, Park, YS, Yang, E, Jung, DI, Rho, S, Park, U, Sung, H, Park, PG, Choi, JA, Seo, SH, Cho, NH, Lee, H, Lee, JM, Kim, JO, \& Song, M. (2020). Characterization of novel monoclonal antibodies against MERScoronavirus spike protein. Virus Res., 278, 197863. doi:10.1016/j.virusres.2020.197863. PMID: 31945421.

32. Zeng, $L P, G e, X Y$, Peng, $C$, Tai, $W$, Jiang, $S$, Du, L, Shi, ZL. (2017). Cross-neutralization of SARS coronavirus-specific antibodies against bat SARS-like coronaviruses. Sci China Life Sci., 60(12), 1399-1402. doi:10.1007/ s11427-017-9189-3. PMID: 29134417; PMCID: PMC7089274.

33. Cohen, J. (2020). New coronavirus threat galvanizes scientists. Science, 367(6477), 492-93. doi:10.1126/science.367.6477.492. PMID: 32001631.

34. Dhama, K, Sharun, K, Tiwari, R, Dadar, M, Malik, YS, Singh, KP, \& Chaicumpa, W. (2020). COVID-19, an emerging coronavirus infection: advances and prospects in designing and developing vaccines, immunotherapeutics, and therapeutics. Hum Vaccin Immunother., 16(6), 1232-1238. doi: 10.1080/21645515.2020.1735227. PMID: 32186952 ; PMCID: PMC7103671.

\section{РЕЗЮME}

\section{ОСОБЛИВОСТІ ПРОТИВІРУСНИХ АНТИТІЛ ПРИ COVID-19 ТА ПЕРСПЕКТИВИ ÏХ ВИКОРИСТАННЯ В КЛІНІЧНІЙ ПРАКТИЦІ}

\author{
Лісяний М.I.
}

Відділ нейроімунології ДУ «Інститут нейрохірургії НАМНУ»

Роль імунних реакцій як клітинного, так і гуморального типу в патогенезі COVID-19, неоднозначна та суперечлива. В представленому огляді літератури аналізуються два погляди на цю проблему, а саме захисну та стимулюючу вірусну інфекцію, імунопатологічна роль різних імунних клітин, особливо антитіл. Приведені дані про направленість та рівень нейтралізуючих і не нейтралізуючих віруси антитіл в крові хворих, реконвалесцентів та здорових осіб і відмічається, що до 30-50\% пацієнтів мають низькі рівні вірус нейтралізуючих антитіл, а це ускладнює можливості використання антитіл для профілактики та лікування тяжких форм захворювання. Характеризується антиген специфічний та неспецифічний механізми дії антитіл при корона інфекції, які по-різному впливають на перебіг захворювання. В огляді коротко обговорюються проблеми, пов'язані з отриманням та використанням різних типів моноклональних антитіл для лікування тяжко хворих. В статті робиться висновок, що імунні препарати із крові реконвалесцентів та моноклональні антитіла, які містять великий рівень нейтралізуючих антитіл, можуть бути одним із специфічних методів лікування COVID-19.
Ключові слова: інфекція COVID-19, імунітет, нейтралізуючі антитіла, імунні препарати із крові реконвалесцентів.

\section{RESUME}

FEATURES OF ANTI-VIRAL ANTIBODIES IN COVID-19 AND THE PROSPECTS OF THEIR USE IN CLINICAL PRACTICE

Lisyany $N$.

Department of Neuroimmunology, Institute of Neurosurgery, National Academy of Medical Sciences of Ukraine

The role of both cellular and humoral immune responses in the pathogenesis of COVID-19 is ambiguous and controversial. The presented literature review analyzes two views on this problem, namely the protective and stimulating viral infection (immune-pathological) role of various immune cells, especially antibodies. Data on the direction and level of neutralizing and non-neutralizing antibodies in the blood of patients, convalescents and healthy individuals and it is noted that up to $30-50 \%$ of patients have low levels of virus neutralizing antibodies, which complicates the use of antibodies for prevention and treatment of severe diseases. It is characterized by antigen-specific and nonspecific mechanisms of action of antibodies in corona infection, which differently affect the course of the disease. The review briefly discusses the problems associated with obtaining and using different types of monoclonal antibodies to treat critically ill patients. The article concludes that immune drugs from convalescent blood, which contains a high level of neutralizing antibodies, are currently the specific method of treatment for COVID - 19.

Key words: COVID -19 infection, immunity, neutralizing antibodies, immune drugs from convalescent blood.

\section{РЕЗЮMЕ}

ОСОБЕННОСТИ ГУМОРАЛЬНОГО ИММУНИТЕТА ПРИ COVID-19 И ПЕРСПЕКТИВЫ ИСПОЛЬЗОВАНИЯ ПРОТИВОВИРУСНЫХ АНТИТЕЛ В КЛИНИЧЕСКОЙ ПРАКТИКЕ

\author{
Лисяный Н.И. \\ Отдел нейроиммунологии \\ ГУ «Институт нейрохирургии НАМНУ»
}

Роль иммунных реакций как клеточного, так и гуморального типа в патогенезе COVID-19 не однозначна и противоречива. В представленном обзоре литературы анализируются два взгляда на эту проблему, а именно - защитную и стимулирующую вирусную инфекцию иммунопатологическую роль различных иммунных клеток, особенно антител. Приведены данные о направленности и уровень нейтрализующих и не нейтрализующих вирусы антител в крови больных, реконвалесцентов и здоровых лиц, и отмечается, что до 30-50\% пациентов имеют низкие уровни вирус нейтрализующих антител, а это усложняет возможности использования анти- 
тел для профилактики и лечения тяжелых форм заболевания. Характеризуется антигенспецифический и не специфический механизмы действия антител при корона инфекции, которые по-разному влияют на течение заболевания. В обзоре кратко обсуждаются проблемы, связанные с получением и использованием различных типов моноклональных антител для лечения тяжелобольных. В статье делается вывод, что им- мунные препараты из крови реконвалесцентов и моноклональные антитела, которые содержит высокий уровень нейтрализующих антител, может стать специфическим методом лечения COVID-19.

Ключевые слова: инфекция COVID-19, иммунитет, нейтрализующие антитела, иммунные препараты из крови реконвалесцентов.

\section{АВТОРСЬКА ДОВІДКА}

\section{- Лісяний Микола Іванович}

начальник відділу нейроімунології , чл.-кор. НАМНУ, професор

ORCID: 0000-0002-0498-6247

моб. тел.: 067-595-34-36, раб. тел.: 044483-81-93

Адреса: Інститут нейрохірургії, вул П. Майбороди, 32, Київ - 04050, Україна

E-mail: nimun.neuro@gmail.com

\section{- Лисяный Николай Иванович}

начальник отдела нейроиммунологии, чл.корр. НАМНУ, професор

ORCID: 0000-0002-0498-6247

моб. тел.: 067-595-34-36, раб. тел.: 044483-81-93

Адрес: Институт нейрохирургии, ул. П. Майбороды, 32, Киев - 04050, Украина

E-mail: nimun.neuro@gmail.com

\section{- Lisianyi Mykola}

Head of the Department of Neuroimmunology, Corresponding Member of NAMNU, professor ORCID: 0000-0002-0498-6247

mob. tel.: 067-595-34-36, state tel.: 044-48381-93

Address: Institute of Neurosurgery, $32 \mathrm{P}$. Mayborody Street, Kyiv - 04050, Ukraine E-mail: nimun.neuro@gmail.com 